\title{
Studi Pengambilan Keputusan Investasi Dengan Risiko Pada Pengembangan Proyek Caspian Tower, Grand Sungkono Lagoon Surabaya
}

\author{
Fenny Herwitasari, Christiono Utomo \\ Jurusan Teknik Sipil, Fakultas Teknik Sipil dan Perencanaan, Institut Teknologi Sepuluh Nopember (ITS) \\ J1. Arief Rahman Hakim, Surabaya 60111 \\ E-mail: fennyherwitasari@gmail.com, christiono@ce.its.ac.id
}

\begin{abstract}
Abstrak - Proyek Caspian Tower, Grand Sungkono Lagoon yang bertempat di Jl. Abdul Wahab Siamin Surabaya merupakan gabungan fungsi hunian apartemen dan pusat perbelanjaan (mall). Proyek ini sangat menarik karena mencoba menggabungkan dua market properti berbeda yang dapat memunculkan risiko dan tingkat pengembalian investasi yang berbeda satu sama lain yang dimungkinkan terjadi saling melemahkan atau memperkuat satu dan lainnya. Penelitian ini bertujuan untuk mendapatkan keputusan terbaik dalam investasi dilihat dari risiko dan tingkat keuntungan yang didapat.

Untuk menentukan fungsi bangunan terbaik, dianalisa 2 alternatif lain selain penggabungan antara apartemen dan mall, yaitu pembangunan perkantoran dan pembangunan hotel. Dari hasil kuesioner yang disebar, didapatkan probabilitas untuk apartemen mall: optimis=70,7\%, moderat $=20,1 \%$, pesimis=9,2\%; Perkantoran: optimis $=$ 57,1\%, moderat $=28,6 \%$, pesimis $=14,3 \%$; Hotel: optimis $=$ $64,8 \%$, moderat $=23 \%$, pesimis $=12,2 \%$. Berdasarkan perhitungan NPV risiko, didapatkan keputusan investasi terbaik adalah investasi apartemen dan mall dengan NPV risiko sebesar Rp.341.209.972.609,37 yang lebih besar dibandingkan dengan hasil NPV risiko perkantoran dan hotel yaitu sebesar Rp.326.927.631.618,04 dan Rp. 321.827.486.548,59.

Dari hasil analisa investasi dan analisa risiko dapat disimpulkan bahwa alternatif investasi yang menghasilkan tingkat keuntungan pada risiko yang bisa diterima paling besar adalah alternatif apartemen dan mall. Sedangkan alternatif investasi yang menghasilkan tingkat keuntungan pada risiko yang bisa diterima paling rendah adalah alternatif hotel.
\end{abstract}

Kata kunci: Pengambilan Keputusan, Risiko, Investasi, Caspian Tower

\section{PENDAHULUAN}

\subsection{Latar Belakang}

Surabaya yang merupakan salah satu kota metropolitan terbesar di Indonesia. Hal ini tentu menarik minat para investor untuk melirik Surabaya menjadi salah satu tujuan investasi mereka dalam pembangunan properti di Surabaya. Properti sendiri terlihat seperti investasi yang menghasilkan banyak keuntungan, tetapi jika diteliti lebih lanjut sesungguhnya mengandung risiko yang tinggi.

Pada tahun 2015, di Surabaya telah dimulai pembangunan apartemen baru, yaitu Caspian Tower, Grand Sungkono Lagoon bertempat di Jl. Abdul Wahab Siamin no. 9 dan akan dibangun sebanyak 48 lantai. Pada umumnya para developer mengembangkan properti secara terpisah, yaitu apartemen saja atau mall saja. Sedangkan Caspian Tower merupakan gabungan fungsi hunian apartemen dan mall, sehingga membuat proyek ini menarik untuk dianalisa risiko terhadap investasinya karena dimungkinkan terjadi saling melemahkan atau memperkuat satu dengan lainnya. Dengan melihat hal tersebut, sebagai perbandingan untuk melihat besarnya risiko pendapatan dan mungkin dapat digunakan untuk pengambilan keputusan investasi di masa datang, dianalisa 2 alternatif lain selain penggabungan antara apartemen dan mall yaitu alternatif perkantoran serta alternatif hotel. Berdasarkan latar belakang tersebut maka perlu dilakukan studi mengenai pengambilan keputusan dengan risiko terhadap investasi proyek Caspian Tower, Grand Sungkono Lagoon Surabaya.

\subsection{Jenis Penelitian}

\section{URAIAN PENELITIAN}

Jenis penelitian ini berupa analisa investasi dengan risiko pengambilan keputusan yang bertujuan untuk menentukan alternatif mana yang paling baik sebagai keputusan investasi proyek Caspian Tower dengan pertimbangan tingkat pengembalian dan risiko.

\subsection{Penelitian Terdahulu}

Penelitian Analisa Investasi Dengan Resiko Pada Investasi Proyek Golden City Mall Surabaya [1] bertujuan meneliti mengenai analisa risiko terhadap investasi proyek untuk memperoleh besarnya tingkat pengembalian investasi dan keputusan alternatif investasi melalui pertimbangan tingkat pengembalian dan risiko.

Penelitian Analisa Pembiayaan Investasi Properti Perkantoran di Jakarta Selatan [2] bertujuan untuk mengetahui komposisi pembiayaan yang paling menguntungkan pada pembangunan Properti Perkantoran Nifarro Office Tower-Sky18 menggunakan 4 alternatif.

Penelitian Analisa Pembeayaan Investasi Proyek Apartemen Puncak Kertajaya Surabaya [3] bertujuan untuk mengetahui bentuk pembiayaan yang paling menguntungkan dalam proyek pembangunan Apartemen Puncak Kertajaya menggunakan 4 alternatif yang berbeda.

Penelitian Analisis Investasi pada Proyek Pembangunan Apartemen Bale Hinggil Surabaya [4] bertujuan untuk mendapatkan alternatif pendapatan yang maksimal dari alternatif pendapatan antara apartemen sewa, jual, dan gabungan keduanya dengan penilaian kelayakan investasi menggunakan metode NPV dan IRR.

Penelitian Analisis Pembeayaan Invetasi Proyek Perumahan Green Pakis Regency Malang [5] bertujuan untuk menentukan bentuk pembiayaan dan tingkat pengembalian yang paling ringan dengan menggunakan metode WACC dan metode leverage.

Penelitian Analisa Pembiayaan Invetasi Apartemen Puri Park View Tower E Kebon Jeruk - Jakarta Barat [6] bertujuan untuk memperoleh sumber pembeayaan proyek 
dengan 4 alternatif yaitu modal sendiri dan pinjaman dengan kriteria penganggaran modal.

\subsection{Data Penelitian}

\section{III.METODOLOGI}

Data tediri dari data primer dan sekunder. Data Primer diperoleh melalui wawancara dengan pihak pengelola untuk mengetahui konsep pengelolaan. Data primer juga diperoleh dari wawancara dan kuesioner dengan responden praktisi untuk menentukan alternatif investasi dan juga mengetahui angka probabiltas dari kondisi tiap alternatif investasi. Kemudian data sekunder yang diperoleh berupa gambar proyek serta data mengenai harga jual unit Caspian Tower.

\subsection{Analisa Data}

\subsubsection{Data Analisa Investasi}

Untuk membuat perkiraan pendapatan dan pengeluaran di masa yang akan datang, diperlukan beberapa asumsi dan peramalan pendapatan sebagai berikut:

1. Skenario moderat didasarkan pada tingkat hunian ruang ritel rata-rata di Surabaya sebesar $70 \%$ yang kemudian dianggap sebagai kondisi umum atau asumsi normal dalam Tugas Akhir ini.

2. Skenario optimis dan pesimis diasumsikan pada kondisi tingkat hunian ruang ritel di Surabaya, dalam Tugas Akhir ini diasumsikan sebesar $94 \%$ dan $46 \%$.

3. Peramalan pendapatan dan estimasi biaya menggunakan metode forecasting (peramalan) dari data yang berupa perkiraan-perkiraan biaya.

4. Analisa Arus Kas dan Analisa Aspek Finansial diperoleh dari data yang berupa perkiraan-perkiraan biaya maupun pemasukan yang dikelompokkan sesuai dengan jenisnya. Setelah itu dibuatlah sebuah cash flow terhadap tiap-tiap tahun selama masa investasi sehingga diperoleh keuntungan dan kerugian tiap tahun.

\subsubsection{Data Analisa Risiko}

Pada tahap analisa data untuk risiko, kuesioner yang telah diisi oleh responden dinilai berdasarkan bobot. Jumlah item pertanyaan sebanyak empat buah dengan skala bobot 1 sampai dengan 9.

Setelah itu dilakukan analisa probabilitas dengan metode AHP yang bertujuan untuk mendapatkan probabilitas dari masing-masing alternatif. Baru setelah itu dilakukan proses penghitungan besarnya NPV risiko dari jumlah hasil kali antara probabilitas masing-masing alternatif dengan NPV yang didapat pada setiap kondisi okupansi. Masing-masing alternatif nantinya akan memiliki nilai NPV risiko, dan untuk mengambil keputusan investasi yang paling menguntungkan, dipilih berdasarkan NPV risiko terbesar.
Proses yang dilakukan dalam penelitian ini adalah sebagai berikut:

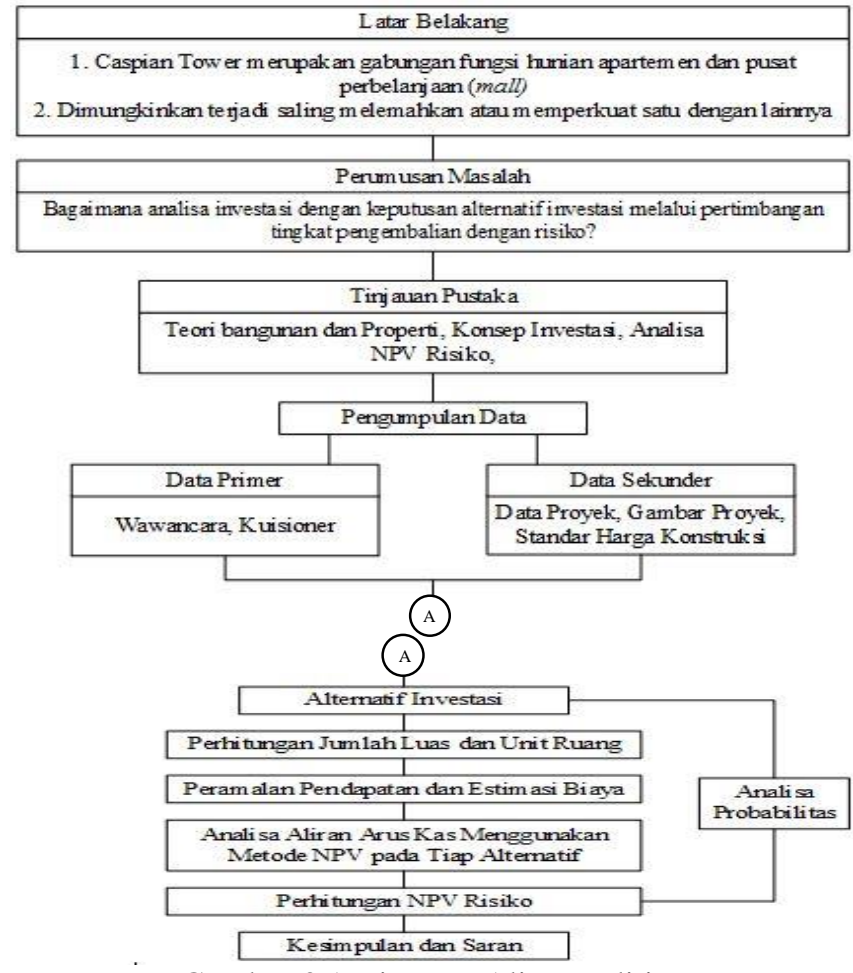

Gambar 3.1 Diagram Alir Penelitian

\section{HASIL PENELITIAN}

\subsection{Alternatif Proyek}

Alternatif lain yang dipilih dalam penulisan Tugas Akhir ini adalah pembangunan Caspian Tower menjadi apartemen mall, perkantoran, dan hotel.

4.1.1. Analisa Luasan Bangunan

a. Koefisien Dasar Bangunan (KDB)

KDB yang disyaratkan maksimum sebesar 55\% [7], jadi batas luas tanah yang boleh dibangun sebesar 19,535 m2.

b. Koefisien Lantai Bangunan (KLB)

KLB yang disyaratkan maksimum sebesar $1200 \%$ dari luas lahan. Jadi maksimal luas lantai yang akan dimanfaatkan dalam alternatif tidak melebihi dari 426,180 m2.

c. Penentuan Jumlah Lantai

Pada lahan ini ketinggian maksimum yang diberikan oleh Pemerintah Kota Surabaya adalah 200 m di atas permukaan laut. Sedangkan lokasi lahan Caspian Tower sendiri berada $22 \mathrm{~m}$ di atas permukaan laut, sehingga tinggi lantai yang akan dibangun tidak boleh melebihi dari $178 \mathrm{~m}$.

\subsubsection{Estimasi Biaya Investasi Alternatif}

Estimasi biaya investasi untuk masing-masing alternatif terdiri dari biaya tanah, biaya perencanaan, biaya konstruksi, dan biaya pengembangan fasilitas. Biaya tanah didapat dari hasil perbandingan harga tanah dengan metode perbandingan data pasar. Sedangkan untuk biaya konstruksi untuk masingmasing alternatif dilakukan dengan pendekatan harga satuan per $\mathrm{m}^{2}$ bangunan. Untuk biaya perencanaan diasumsikan sebesar $15 \%$ dari biaya konstruksi, sedangkan biaya pengembangan fasilitas diasumsikan sebesar 5\% dari biaya konstruksi [8]. Rekapitulasi biaya investasi untuk masingmasing alternatif dapat dilihat pada Tabel 4.1.

Tabel 4.1 Biaya Investasi Alternatif

\begin{tabular}{|c|c|c|}
\hline Apartemen dan Mall & Perkantoran & Hotel \\
\hline Rp 909.813.951.541 & Rp 655.880.748.860 & Rp 719.879.940.102 \\
\hline
\end{tabular}




\subsection{Analisa Investasi}

Analisa investasi dilakukan dengan menggunakan metode Net Present Value (NPV) dan Internal Rate of Return (IRR) yang dilakukan pada 3 alternatif investasi. Setiap alternatif dilakukan analisa dengan 3 kondisi, yaitu optimis, moderat, dan pesimis.

Pembiayaan investasi diperoleh dari modal sendiri sebesar 2/3 dari biaya investasi awal dan modal pinjaman dari bank. Pengembalian pinjaman ini akan diangsur selama sepuluh tahun dengan bunga 10,35\% pertahunnya. Kemudian untuk menghitung aliran kas (cash flow) digunakan besaran faktor diskon dari Minimum Attractive Rate of Return (MARR) sebesar $11,24 \%$.

\subsubsection{Perencanaan Pendapatan}

Perencanaan pendapatan untuk alternatif bangunan berasal dari penjualan/penyewaan dan service charge. Rekapitulasi pendapatan untuk masing-masing alternatif di tiap kondisi dapat dilihat pada Tabel 4.2, Tabel 4.3, dan Tabel 4.4.

Tabel 4.2 Pendapatan Alternatif Apartemen dan Mall

\begin{tabular}{|c|c|c|c|}
\hline Tahun & Optimis & Moderat & Pesimis \\
\hline 2016 & $\operatorname{Rp} 310.553 .661 .399$ & $\operatorname{Rp} 259.360 .468 .866$ & $\begin{array}{ll}\mathrm{Rp} & 190.142 .796 .902\end{array}$ \\
\hline 2017 & Rp 549.783.538.040 & Rp 424.522.779.157 & Rp 308.915 .322 .256 \\
\hline 2018 & Rp 557.735.598.230 & Rp 554.209.179.894 & Rp 391.662.348.007 \\
\hline 2019 & $\operatorname{Rp} 317.489 .500 .751$ & $\operatorname{Rp} 348.913 .769 .028$ & Rp 417.609.512.367 \\
\hline 2020 & Rp $\quad 87.874 .800 .064$ & Rp 191.082.532.296 & Rp 303.883 .958 .176 \\
\hline 2021 & $\begin{array}{ll}\text { Rp } & 87.874 .800 .064 \\
\end{array}$ & $\begin{array}{ll}\mathrm{Rp} & 67.317 .878 .509\end{array}$ & Rp 225.028.366.136 \\
\hline 2022 & $\begin{array}{ll}\operatorname{Rp} & 97.939 .126 .242 \\
\end{array}$ & $\mathrm{Rp} \quad 74.812 .589 .492$ & $\begin{array}{ll}\operatorname{Rp} & 51.686 .052 .743 \\
\end{array}$ \\
\hline 2023 & Rp $\quad 97.939 .126 .242$ & Rp 74.812 .589 .492 & Rp $\quad 51.686 .052 .743$ \\
\hline 2024 & Rp 109.997 .512 .256 & $\begin{array}{ll}\mathrm{Rp} & 83.980 .158 .413 \\
\end{array}$ & Rp $\quad 57.962 .804 .570$ \\
\hline 2025 & $\operatorname{Rp} 109.997 .512 .256$ & $\begin{array}{ll}\operatorname{Rp} & 83.980 .158 .413\end{array}$ & $\begin{array}{ll}\text { Rp } & 57.962 .804 .570 \\
\end{array}$ \\
\hline 2026 & Rp 122.735 .175 .075 & Rp 93.465 .652 .001 & Rp $\quad 64.196 .128 .928$ \\
\hline 2027 & Rp 122.735.175.075 & $\mathrm{Rp} \quad 93.465 .652 .001$ & Rp $\quad 64.196 .128 .928$ \\
\hline 2028 & Rp 137.874 .666 .717 & Rp 104.946.453.259 & $\begin{array}{ll}\operatorname{Rp} & 72.018 .239 .801\end{array}$ \\
\hline 2029 & Rp 137.874 .666 .717 & Rp 104.946.453.259 & $\begin{array}{ll}\mathrm{Rp} & 72.018 .239 .801 \\
\end{array}$ \\
\hline 2030 & Rp 153.995.771.222 & Rp 116.951.531.082 & Rp $\quad 79.907 .290 .942$ \\
\hline 2031 & Rp 153.995.771.222 & $\operatorname{Rp} 116.951 .531 .082$ & $\begin{array}{ll}\text { Rp } & 79.907 .290 .942 \\
\end{array}$ \\
\hline 2032 & Rp 173.022 .596 .858 & Rp 131.347.826.701 & $\begin{array}{ll}\mathrm{Rp} & 89.673 .056 .543 \\
\end{array}$ \\
\hline 2033 & Rp 173.022.596.858 & Rp 131.347.826.701 & Rp $\quad 89.673 .056 .543$ \\
\hline 2034 & $\operatorname{Rp} 193.425 .869 .747$ & $\operatorname{Rp} 146.541 .753 .320$ & $\begin{array}{ll}R p & 99.657 .636 .893 \\
\end{array}$ \\
\hline 2035 & Rp 193.425.869.747 & $\operatorname{Rp} 146.541 .753 .320$ & $\begin{array}{ll}\mathrm{Rp} & 99.657 .636 .893 \\
\end{array}$ \\
\hline
\end{tabular}

Tabel 4.3 Pendapatan Alternatif Perkantoran

\begin{tabular}{|r|c|c|c|}
\hline Tahun & Optimis & Moderat & Pesimis \\
\hline 2016 & $R p 135.564 .222 .690$ & $R p 109.273 .781 .939$ & $R p \quad 84.359 .221 .605$ \\
\hline 2017 & $R p 135.564 .222 .690$ & $R p 109.273 .781 .939$ & $R p \quad 84.359 .221 .605$ \\
\hline 2018 & $R p 151.524 .395 .185$ & $R p 122.196 .323 .608$ & $R p \quad 94.415 .909 .944$ \\
\hline 2019 & $R p 151.524 .395 .185$ & $R p 122.196 .323 .608$ & $R p \quad 94.415 .909 .944$ \\
\hline 2020 & $R p 169.381 .053 .707$ & $R p 136.660 .514 .879$ & $R p 105.680 .862 .888$ \\
\hline 2021 & $R p 169.381 .053 .707$ & $R p 136.660 .514 .879$ & $R p 105.680 .862 .888$ \\
\hline 2022 & $R p 189.361 .405 .457$ & $R p 152.851 .695 .141$ & $R p 118.300 .231 .371$ \\
\hline 2023 & $R p 189.361 .405 .457$ & $R p 152.851 .695 .141$ & $R p 118.300 .231 .371$ \\
\hline 2024 & $R p 211.720 .073 .179$ & $R p 170.977 .634 .526$ & $R p 132.437 .946 .976$ \\
\hline 2025 & $R p 211.720 .073 .179$ & $R p 170.977 .634 .526$ & $R p 132.437 .946 .976$ \\
\hline 2026 & $R p 236.742 .423 .571$ & $R p 191.271 .264 .083$ & $R p 148.277 .895 .700$ \\
\hline 2027 & $R p 236.742 .423 .571$ & $R p 191.271 .264 .083$ & $R p 148.277 .895 .700$ \\
\hline 2028 & $R p 264.748 .301 .886$ & $R p 213.993 .739 .859$ & $R p 166.026 .358 .550$ \\
\hline 2029 & $R p 264.748 .301 .886$ & $R p 213.993 .739 .859$ & $R p 166.026 .358 .550$ \\
\hline 2030 & $R p 296.096 .222 .527$ & $R p 239.437 .881 .884$ & $R p 185.914 .751 .845$ \\
\hline 2031 & $R p 296.096 .222 .527$ & $R p 239.437 .881 .884$ & $R p 185.914 .751 .845$ \\
\hline 2032 & $R p 331.188 .071 .539$ & $R p 267.932 .034 .115$ & $R p 208.202 .704 .150$ \\
\hline 2033 & $R p 331.188 .071 .539$ & $R p 267.932 .034 .115$ & $R p 208.202 .704 .150$ \\
\hline 2034 & $R p 370.474 .383 .797$ & $R p 299.844 .397 .075$ & $R p 233.181 .511 .324$ \\
\hline 2035 & $R p 370.474 .383 .797$ & $R p 299.844 .397 .075$ & $R p 233.181 .511 .324$ \\
\hline
\end{tabular}

Tabel 4.4 Pendapatan Alternatif Hotel

\begin{tabular}{|r|c|c|c|}
\hline Tahun & Optimis & Moderat & Pesimis \\
\hline 2016 & $R p 230.679 .406 .882$ & $R p 170.530 .222 .146$ & $R p 112.483 .137 .410$ \\
\hline 2017 & $R p 230.679 .406 .882$ & $R p 170.530 .222 .146$ & $R p 112.483 .137 .410$ \\
\hline 2018 & $R p 237.333 .620 .542$ & $R p 175.449 .363 .170$ & $R p 115.727 .843 .297$ \\
\hline 2019 & $R p 237.333 .620 .542$ & $R p 175.449 .363 .170$ & $R p 115.727 .843 .297$ \\
\hline 2020 & $R p 267.000 .323 .110$ & $R p 197.380 .533 .566$ & $R p 130.193 .823 .709$ \\
\hline 2021 & $R p 267.000 .323 .110$ & $R p 197.380 .533 .566$ & $R p 130.193 .823 .709$ \\
\hline 2022 & $R p 275.422 .062 .274$ & $R p 203.606 .321 .424$ & $R p 134.300 .404 .598$ \\
\hline 2023 & $R p 275.422 .062 .274$ & $R p 203.606 .321 .424$ & $R p 134.300 .404 .598$ \\
\hline 2024 & $R p 309.849 .820 .058$ & $R p 229.057 .111 .602$ & $R p 151.087 .955 .172$ \\
\hline 2025 & $R p 309.849 .820 .058$ & $R p 229.057 .111 .602$ & $R p 151.087 .955 .172$ \\
\hline 2026 & $R p 320.508 .583 .687$ & $R p 236.936 .624 .359$ & $R p 156.285 .346 .609$ \\
\hline 2027 & $R p 320.508 .583 .687$ & $R p 236.936 .624 .359$ & $R p 156.285 .346 .609$ \\
\hline 2028 & $R p 360.572 .156 .648$ & $R p 266.553 .702 .404$ & $R p 175.821 .014 .935$ \\
\hline 2029 & $R p 360.572 .156 .648$ & $R p 266.553 .702 .404$ & $R p 175.821 .014 .935$ \\
\hline 2030 & $R p 374.062 .154 .365$ & $R p 276.526 .210 .738$ & $R p 182.398 .963 .471$ \\
\hline 2031 & $R p 374.062 .154 .365$ & $R p 276.526 .210 .738$ & $R p 182.398 .963 .471$ \\
\hline 2032 & $R p 420.819 .923 .661$ & $R p 311.091 .987 .080$ & $R p 205.198 .833 .905$ \\
\hline 2033 & $R p 420.819 .923 .661$ & $R p 311.091 .987 .080$ & $R p 205.198 .833 .905$ \\
\hline 2034 & $R p 437.893 .202 .022$ & $R p 323.713 .442 .940$ & $R p 213.524 .050 .022$ \\
\hline 2035 & $R p 437.893 .202 .022$ & $R p 323.713 .442 .940$ & $R p 213.524 .050 .022$ \\
\hline
\end{tabular}

\subsubsection{Perencanaan Pengeluaran}

Perencanaan pengeluaran untuk tiap alternatif berasal dari biaya operasional (listrik, air, dan gaji karyawan), pemeliharaan, dan penggantian. Rekapitulasi pengeluaran untuk tiap alternatif dalam kondisi optimis, moderat, dan pesimis dapat dilihat pada Tabel 4.5, Tabel 4.6, dan Tabel 4.7.

Tabel 4.5 pengeluaran Alternatif Apartemen dan Mall

\begin{tabular}{|c|c|c|c|}
\hline Tahun & Optimis & Moderat & Pesimis \\
\hline 2016 & $R p 34.942 .139 .489$ & $R p 31.115 .089 .019$ & $R p 26.718 .091 .073$ \\
\hline 2017 & $R p 38.225 .911 .810$ & $R p 33.984 .682 .582$ & $R p 29.132 .349 .273$ \\
\hline 2018 & $R p 41.204 .660 .631$ & $R p 36.525 .890 .067$ & $R p 31.194 .858 .820$ \\
\hline 2019 & $R p 43.061 .118 .483$ & $R p 38.214 .138 .003$ & $R p 32.673 .740 .236$ \\
\hline 2020 & $R p 49.029 .029 .916$ & $R p 43.237 .935 .384$ & $R p 36.712 .266 .963$ \\
\hline 2021 & $R p 48.155 .502 .425$ & $R p 42.714 .070 .192$ & $R p 36.496 .907 .466$ \\
\hline 2022 & $R p 51.171 .074 .991$ & $R p 45.264 .054 .452$ & $R p 38.540 .146 .817$ \\
\hline 2023 & $R p 53.024 .791 .592$ & $R p 46.947 .091 .352$ & $R p 40.011 .347 .414$ \\
\hline 2024 & $R p 56.582 .479 .798$ & $R p 49.996 .466 .524$ & $R p 42.511 .252 .948$ \\
\hline 2025 & $R p 61.874 .491 .801$ & $R p 54.459 .720 .194$ & $R p 46.104 .591 .681$ \\
\hline 2026 & $R p 61.882 .553 .221$ & $R p 54.563 .548 .545$ & $R p 46.263 .030 .360$ \\
\hline 2027 & $R p 63.785 .482 .223$ & $R p 56.283 .265 .582$ & $R p 47.758 .378 .830$ \\
\hline 2028 & $R p 67.781 .837 .156$ & $R p 59.669 .084 .835$ & $R p 50.492 .505 .800$ \\
\hline 2029 & $R p 69.770 .345 .853$ & $R p 61.466 .913 .804$ & $R p 52.058 .498 .437$ \\
\hline 2030 & $R p 78.121 .326 .242$ & $R p 68.217 .877 .058$ & $R p 57.168 .287 .954$ \\
\hline 2031 & $R p 75.558 .968 .053$ & $R p 66.385 .036 .122$ & $R p 56.023 .807 .669$ \\
\hline 2032 & $R p 80.104 .175 .190$ & $R p 70.190 .330 .709$ & $R p 59.048 .033 .102$ \\
\hline 2033 & $R p 82.168 .391 .792$ & $R p 72.046 .014 .948$ & $R p 60.654 .028 .375$ \\
\hline 2034 & $R p 86.562 .829 .716$ & $R p 75.623 .484 .979$ & $R p 63.373 .373 .909$ \\
\hline 2035 & $R p 94.189 .626 .436$ & $R p 81.855 .859 .392$ & $R p 68.170 .169 .412$ \\
\hline
\end{tabular}

Tabel 4.6 Pengeluaran Alternatif Perkantoran

\begin{tabular}{|r|c|c|c|}
\hline Tahun & Optimis & Moderat & Pesimis \\
\hline 2016 & $R p 25.114 .003 .018$ & $R p 19.941 .578 .224$ & $R p 14.773 .470 .646$ \\
\hline 2017 & $R p 28.259 .740 .903$ & $R p 22.377 .102 .397$ & $R p 16.499 .373 .893$ \\
\hline 2018 & $R p 31.119 .252 .768$ & $R p 24.598 .635 .451$ & $R p 18.083 .460 .632$ \\
\hline 2019 & $R p 31.813 .562 .935$ & $R p 25.201 .399 .071$ & $R p 18.594 .754 .115$ \\
\hline 2020 & $R p 39.230 .405 .853$ & $R p 30.830 .128 .886$ & $R p 22.436 .863 .295$ \\
\hline 2021 & $R p 35.112 .891 .654$ & $R p 27.835 .428 .946$ & $R p 20.564 .040 .444$ \\
\hline 2022 & $R p 37.978 .804 .253$ & $R p 30.061 .747 .380$ & $R p 22.151 .298 .557$ \\
\hline 2023 & $R p 38.660 .131 .671$ & $R p 30.654 .804 .709$ & $R p 22.656 .159 .472$ \\
\hline 2024 & $R p 41.779 .091 .202$ & $R p 33.070 .308 .584$ & $R p 24.368 .794 .839$ \\
\hline 2025 & $R p 48.265 .964 .118$ & $R p 38.003 .765 .061$ & $R p 27.750 .131 .451$ \\
\hline 2026 & $R p 45.893 .017 .062$ & $R p 36.313 .355 .603$ & $R p 26.741 .689 .904$ \\
\hline 2027 & $R p 46.647 .720 .535$ & $R p 36.961 .271 .061$ & $R p 27.282 .906 .479$ \\
\hline 2028 & $R p 50.352 .020 .672$ & $R p 39.814 .393 .051$ & $R p 29.285 .560 .765$ \\
\hline 2029 & $R p 51.149 .038 .134$ & $R p 40.493 .943 .710$ & $R p 29.847 .742 .667$ \\
\hline 2030 & $R p 62.871 .327 .189$ & $R p 49.341 .553 .604$ & $R p 35.823 .072 .779$ \\
\hline 2031 & $R p 56.034 .174 .877$ & $R p 44.313 .571 .011$ & $R p 32.602 .749 .863$ \\
\hline 2032 & $R p 60.446 .749 .796$ & $R p 47.696 .220 .374$ & $R p 34.956 .333 .307$ \\
\hline 2033 & $R p 61.341 .512 .687$ & $R p 48.448 .848 .435$ & $R p 35.566 .945 .173$ \\
\hline 2034 & $R p 66.162 .188 .796$ & $R p 52.136 .606 .431$ & $R p 38.122 .730 .658$ \\
\hline 2035 & $R p 76.406 .937 .085$ & $R p 59.879 .562 .734$ & $R p 43.365 .983 .120$ \\
\hline
\end{tabular}


Tabel 4.7 Pengeluaran Alternatif Hotel

\begin{tabular}{|c|c|c|c|}
\hline Tahun & Optimis & Moderat & Pesimis \\
\hline 2016 & Rp 68.645 .088 .209 & Rp 56.193 .487 .786 & Rp $\quad 42.926 .362 .074$ \\
\hline 2017 & Rp 75.394 .693 .927 & Rp $\quad 61.582 .748 .842$ & Rp $\quad 46.897 .596 .813$ \\
\hline 2018 & Rp $\quad 82.449 .754 .669$ & Rp $\quad 67.197 .818 .147$ & Rp $\quad 51.017 .776 .532$ \\
\hline 2019 & Rp 85.983 .430 .030 & Rp 70.209 .696 .124 & $\mathrm{Rp} \quad 53.420 .869 .835$ \\
\hline 2020 & Rp 99.661 .697 .830 & Rp 80.720 .984 .759 & Rp $\quad 60.770 .636 .102$ \\
\hline 2021 & Rp 96.424 .430 .329 & $\mathrm{Rp} \quad 78.727 .429 .413$ & $\mathrm{Rp} \quad 59.872 .104 .408$ \\
\hline 2022 & Rp 103.846 .192 .412 & Rp 84.613 .583 .432 & $\mathrm{Rp} \quad 64.171 .093 .834$ \\
\hline 2023 & Rp 107.412 .159 .067 & Rp 87.649 .332 .815 & Rp $\quad 66.589 .932 .913$ \\
\hline 2024 & Rp 115.392 .527 .476 & Rp 93.948 .437 .700 & Rp 71.161 .308 .127 \\
\hline 2025 & Rp 127.562 .571 .913 & Rp 103.344 .769 .137 & Rp $\quad 77.775 .639 .455$ \\
\hline 2026 & Rp 127.644 .870 .465 & Rp 103.805.209.767 & $\mathrm{Rp} \quad 78.495 .783 .694$ \\
\hline 2027 & Rp 131.374.690.757 & Rp 106.962.088.286 & Rp $\quad 80.994 .520 .547$ \\
\hline 2028 & Rp 140.691.573.596 & Rp 114.249.214.190 & $\mathrm{Rp} \quad 86.217 .602 .554$ \\
\hline 2029 & Rp 144.519 .031 .491 & Rp 117.478 .271 .506 & Rp 88.763 .949 .135 \\
\hline 2030 & Rp 166.772 .932 .759 & Rp 134.329 .114 .677 & Rp 100.295 .337 .728 \\
\hline 2031 & Rp 158.569.235.083 & Rp 128.664.115.692 & Rp $\quad 96.975 .091 .606$ \\
\hline 2032 & Rp 169.577.661.461 & Rp 137.201 .718 .608 & Rp 103.022.998.537 \\
\hline 2033 & Rp 173.638.534.405 & Rp 140.603.328.475 & Rp 105.683 .162 .200 \\
\hline 2034 & Rp 185.654.424.221 & Rp 149.885 .700 .793 & Rp 112.222 .325 .156 \\
\hline 2035 & Rp 205.220.266.949 & Rp 164.749 .391 .204 & Rp 122.442 .971 .440 \\
\hline
\end{tabular}

\subsubsection{Biaya Penyusutan}

Biaya penyusutan bangunan menggunakan metode Garis Lurus dengan rencana umur bangunan 20 tahun (UU No. 17 Tahun 2000) dan nilai penyusutan tiap tahun adalah 2,5\% dari biaya investasi. Untuk Apartemen dan Mall sebesar Rp.22.745.348.788,53, Perkantoran Rp.16.397.018.721,49, sedangkan untuk Hotel sebesar Rp.17.996.998.502,56.

\subsubsection{Biaya Pajak}

Menurut UU No. 36 Tahun 2008 di Indonesia mengenai pajak penghasilan, perhitungan pajak dalam negeri dan bentuk usaha tetap adalah sebesar 28\% (dua puluh delapan persen). Maka dalam Tugas Akhir ini dikenakan pula pajak sebesar 28\% dari biaya Pendapatan Kena Pajak (PKP).

\subsubsection{Hasil Analisa Investasi}

Dari hasil analisa investasi diperoleh NPV dan IRR untuk masing-masing alternatif yang dapat dilihat pada Tabel 4.8

\begin{tabular}{|c|l|rr|c|}
\hline Alternatif & Kondisi & \multicolumn{2}{|c|}{ NPV } & IRR \\
\hline \multirow{3}{*}{ Apartemen dan Mall } & Pesimis & $\mathrm{Rp}$ & 189.307 .793 .097 & $15 \%$ \\
\cline { 2 - 5 } & Moderat & $\mathrm{Rp}$ & 278.985 .550 .864 & $20 \%$ \\
\cline { 2 - 5 } & Optimis & $\mathrm{Rp}$ & 378.598 .565 .876 & $25 \%$ \\
\hline \multirow{3}{*}{ Perkantoran } & Pesimis & $\mathrm{Rp}$ & 86.326 .362 .650 & $13 \%$ \\
\cline { 2 - 5 } & Moderat & $\mathrm{Rp}$ & 256.279 .250 .715 & $19 \%$ \\
\cline { 2 - 5 } & Optimis & $\mathrm{Rp}$ & 422.402 .139 .312 & $25 \%$ \\
\hline \multirow{3}{*}{ Hotel } & Pesimis & $\mathrm{Rp}(140.072 .195 .920)$ & $-18 \%$ \\
\cline { 2 - 5 } & Moderat & $\mathrm{Rp}$ & 198.075 .741 .108 & $14 \%$ \\
\cline { 2 - 5 } & Optimis & $\mathrm{Rp}$ & 452.830 .158 .357 & $29 \%$ \\
\hline
\end{tabular}

\subsection{Analisa Probabilitas Alternatif Investasi}

Dalam menganalisa risiko harus diperhitungkan berbagai kondisi aliran kas, kemudian dicari probabilitas terjadinya masing-masing kondisi dengan menggunakan metode Analytic Hierarchy Process (AHP).

\subsubsection{Kuesioner}

Kuesioner terdiri dari empat buah pertanyaan yang nantinya akan dinilai berdasarkan bobot. Skala bobot adalah 1 sampai dengan 9, dengan skala sikap sama, sedikit berbeda, lebih berbeda, sangat berbeda, dan mutlak sangat berbeda.

\subsubsection{Pembobotan Untuk Masing-Masing Kriteria}

Pembobotan dilakukan dengan menggunakan AHP. Pertama dilakukan pembobotan terhadap alternatif untuk kriteria ketidakpastian pendapatan. Data didapatkan dari hasil kuesioner yang disebar kepada manajer proyek dan manajer pemasaran, sehingga didapatkan data yang dapat dibandingkan satu sama lain. Selanjutnya nilai setiap entri pada baris yang sama dirata-rata untuk mendapat matriks perbandingan yang dinormalisasi. Bobot menunjukkan nilai prioritas relatif alternatif tersebut terhadap alternatif lainnya.

Kemudian dilakukan pembobotan menggunakan analisa yang sama untuk kriteria yang lainnya. Setelah menganalisa pembobotan untuk masing-masing kriteria, didapatlah bobot yang kemudian digunakan sebagai probabilitas pada tiap kondisi alternatif. Rekapitulasi angka probabilitas untuk tiap kondisi alternatif dapat dilihat pada Tabel 4.8

Tabel 4.8 Angka Probabilitas Untuk Tiap Kondisi Alternatif

\begin{tabular}{|l|c|c|c|}
\hline & Apartemen dan Mall & Perkantoran & Hotel \\
\hline Optimis & $70,7 \%$ & $57,1 \%$ & $64,8 \%$ \\
\hline Moderat & $20,1 \%$ & $28,6 \%$ & $23,0 \%$ \\
\hline Pesimis & $9,2 \%$ & $14,3 \%$ & $12,2 \%$ \\
\hline
\end{tabular}

\subsubsection{Nilai NPV Risiko}

Setelah diketahui probabilitas terjadinya tiap kondisi aliran kas, maka dapat dihitung nilai NPV risiko dengan cara mengkalikan nilai NPV dengan probabilitas. Rekapitulasi perhitungan untuk NPV Risiko dapat dilihat pada Tabel 4.9.

Tabel 4.9 Perhitungan NPV Risiko

\begin{tabular}{|c|c|c|c|c|}
\hline Alternatif & Kondisi & Probabilitas & NPV & NPV Risiko \\
\hline \multirow{4}{*}{ Apartemen dan Mall } & Pesimis & $9,2 \%$ & 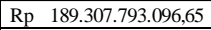 & \begin{tabular}{|ll}
$\mathrm{Rp}$ & $17.326 .887 .866,23$ \\
\end{tabular} \\
\hline & Moderat & $20,1 \%$ & $\begin{array}{|ll|}\text { Rp } 278.985 .550 .864,43 \\
\end{array}$ & $\begin{array}{|ll|}\mathrm{Rp} & 56.191 .056 .393,62 \\
\end{array}$ \\
\hline & Optimis & $70,7 \%$ & Rp $378.598 .565 .875,59$ & \begin{tabular}{|l|l}
$\operatorname{Rp}$ & $267.692 .028 .349,52$ \\
\end{tabular} \\
\hline & & & $\sum$ & $\begin{array}{|ll|}R p & 341.209 .972 .609,37 \\
\end{array}$ \\
\hline \multirow{4}{*}{ Perkantoran } & Pesimis & $14,3 \%$ & $\begin{array}{|ll|}\mathrm{Rp} & 86.326 .362 .649,80 \\
\end{array}$ & \begin{tabular}{|ll}
$\mathrm{Rp}$ & $12.332 .337 .521,40$ \\
\end{tabular} \\
\hline & Moderat & $28,6 \%$ & $\begin{array}{|ll|}\operatorname{Rp} & 256.279 .250 .714,82 \\
\end{array}$ & $\begin{array}{|ll|}\mathrm{Rp} & 73.222 .643 .061,38 \\
\end{array}$ \\
\hline & Optimis & $57,1 \%$ & $\begin{array}{ll}\text { Rp } & 422.402 .139 .311,72 \\
\end{array}$ & \begin{tabular}{|ll} 
Rp & $241.372 .651 .035,27$ \\
\end{tabular} \\
\hline & & & $\sum$ & Rp $326.927 .631 .618,04$ \\
\hline \multirow{4}{*}{ Hotel } & Pesimis & $12,2 \%$ & $\mathrm{Rp}(140.072 \cdot 195.920,22)$ & \begin{tabular}{|ll}
$\operatorname{Rp}$ & $(17.114 .296 .079,62$ \\
\end{tabular} \\
\hline & Moderat & $23,0 \%$ & $\begin{array}{ll}\text { Rp } & 198.075 .741 .107,60\end{array}$ & \begin{tabular}{|ll}
$\mathrm{Rp}$ & $45.531 .903 .451,06$ \\
\end{tabular} \\
\hline & Optimis & $64,8 \%$ & \begin{tabular}{|ll}
$\operatorname{Rp}$ & $452.830 .158 .357,28$ \\
\end{tabular} & $\begin{array}{|ll|}R p & 293.409 .879 .177,15 \\
\end{array}$ \\
\hline & & & $\sum$ & \begin{tabular}{|ll}
$\operatorname{Rp}$ & $321.827 .486 .548,59$ \\
\end{tabular} \\
\hline
\end{tabular}

5.1 Kesimpulan

Dari Seluruh isi Tugas Akhir ini maka dapat ditarik kesimpulan sebagai berikut:

1. Dengan menganalisa reaksi pasar menggunakan metode pendekatan probabilitas statistik, maka diperoleh probabilitas untuk masing-masing alternatif adalah Apartemen dan Mall: optimis=70,7\%, moderat $=20,1 \%$, pesimis $=9,2 \%$; Perkantoran: optimis $=57,1 \%$, moderat $=$ $28,6 \%$, pesimis $=14,3 \%$; Hotel: optimis $=64,8 \%$, moderat $=23 \%$, pesimis $=12,2 \%$.

2. Hasil analisa NPV risiko menunjukkan bahwa NPV risiko terbesar dihasilkan oleh alternatif Apartemen dan Mall. Hal ini ditunjukkan dengan NPV risiko sebesar Rp.341.209.972.609,37 yang lebih tinggi dibandingkan dengan hasil NPV risiko Perkantoran serta Hotel yaitu sebesar Rp. 326.927.631.618,04 dan Rp. 321.827.486.548,59. Maka dapat disimpulkan dari hasil analisa investasi dan analisa risiko bahwa investasi yang mempunyai prospek untuk memperoleh tingkat keuntungan pada risiko yang bisa diterima paling tinggi adalah investasi Apartemen dan Mall.

\subsection{Saran}

Dengan adanya keterbatasan yang terdapat dalam Tugas Akhir ini, meliputi terbatasnya responden untuk penilaian pasar, maka perlu adanya penelitian lebih lanjut tentang analisa risiko dengan populasi responden yang lebih luas sehingga dapat menghasilkan kesimpulan yang lebih mendekati kenyataan. Investasi Proyek Golden City Mall Surabaya. 
Surabaya: Tugas Akhir Jurusan Teknik Sipil, Institut Teknologi Sepuluh Nopember.

[2] Anita Maulanasari dan Christiono Utomo. 2015. Analisa Pembiayaan Investasi Properti Perkantoran di Jakarta Selatan. Jurnal Teknik ITS Vol. 4. No. 2. C51-C55.

[3] M. Awallutfi Andhika Putra dan Christiono Utomo. 2013. Analisa Pembeayaan Investasi Apartemen Puncak Kertajaya Surabaya. Jurnal Teknik ITS Vol.1. No.1. D1-D5.

[4] Ofianto Wahyudhi dan Christiono Utomo. 2014. Analisis Investasi pada Proyek Pembangunan Apartemen Bale Hinggil Surabaya. Jurnal Teknik ITS Vol 3. No.1. D1-D6.

[5] Muhammad Altof Syahrizal dan Christiono Utomo. 2014. Analisa Pembiayaan Investasi Proyek Perumahan Green Pakis Regency Malang. Jurnal Teknik ITS 3(2), C67-C71.

[6] Made Dwiyanti Purnama Ningsih dan Christiono Utomo. 2014. Analisa Pembiayaan Invetasi Apartemen Puri Park View Tower E Kebon Jeruk Jakarta Barat. Jurnal Teknik ITS 3(2). D104-D108.

[7] Rencana Tata Ruang Kota (RTRK) Unit Pengembangan VIII Satelit Kota Surabaya

[8] Juwana. 2005. Panduan Sistem Bangunan Tinggi Untuk Arsitek dan Praktisi Bangunan. Jakarta: Erlangga. 